\title{
Hemşirelerin genetik danışmanlık rollerine ilişkin farkındalı ve yetkinliklerinin belirlenmesi
}

\author{
Yeşim ARSLANTÜRKa ${ }^{\mathrm{a}}$, Gül PINAR ${ }^{\mathrm{b}}$
}

\section{ÖZET}

Amaç: Araştırma, hemşirelerin genetik danışmanlık rollerine ilişkin farkındalıkları ve yetkinliklerinin belirlenmesi amacıyla tanımlayıcı olarak yapıldı. Materyal-Metod: Araştırmanın evrenini, Ankara'da bir eğitim ve araştırma hastanesinde çalışan 600 hemşire oluşturdu. Araştırmaya katılmayı kabul eden 451 hemşire araştırma kapsamına alındı. Veri toplama aracı olarak anket formu kullanıldı. Veriler frekans, yüzdelik, Mann-Whitney U testi, Kruskall-Wallis testleri ile değerlendirildi. Çalışmada anlamlılık düzeyi $\mathrm{p}<0.05$ olarak kabul edildi. Bulgular: Çalışma kapsamında yer alan hemşirelerin yaş ortalaması $30.8 \pm 5.5^{\prime}$ tir. Hemşirelerin \%54.6'sının bekar, \%94.4'ünün lisans ve üzerinde eğitim aldığı, \%87.1'inin servis hemşiresi olarak görev yaptığı belirlendi. Hemşirelerin \%57.7'sinin genetik konusunda bilgi aldıkları, \%81.6'sının genetik bilimindeki gelişmeleri önemsediği, \%32.6'sının ülkemizde genetik danışmanlık hizmetlerini yeterli bulmadığı tespit edildi. Çalışmamızda hemşirelerin genetik bilgi testi puan ortalamalarının $8.25 \pm 2.65(\min =0, \max =13)$ ve genetik hastalıklar bilgi testi puan ortalamalarının ise $6.52 \pm 1.83(\min =0, \max =10)$ olduğu bulundu. Yapılan analizlere göre, genetik bilimindeki gelişmeleri önemseyenlerin, hasta değerlendirme formunda genetik bilgileri kullananların, mevcut genetik danışmanlık hizmetlerini yeterli bulmayanların ve genetik danışmanlık yapmayı isteyenlerin genetik ve genetik hastalıklar bilgi puan ortalamalarının daha yüksek olduğu belirlendi. Eğitim düzeyi yüksek olan hemşirelerde genetik hastalıklar bilgi puan ortalamasının, yoğun bakım deneyimi olan ve yönetici konumunda çalışan hemşirelerde ise genetik bilgi puan ortalamasının daha yüksek olduğu saptandı. Sonuç: Araştırma sonucunda, hemşirelerin genetik danışmanlık rollerine ilişkin farkındalıkları ile yetkinliklerinin yeterli olmadığı bulunmuştur. Bu konuda mezuniyet öncesi ve sonrası eğitim programları ile hemşirelerin yetkin hale getirilmesi ve konuyla ilgili daha ileri çalışmaların yapılması önerilmektedir.

Anahtar Kelimeler: Danışmanlık, hemşirelik, genetik bilimi, yetkinlik

\section{Determining awareness and competency of nurses regarding genetic counseling roles} ABSTRACT

Objective: The research was conducted descriptively to determine the awareness and competencies of nurses regarding their genetic counseling roles. Materials and Methods: The universe of the study consists of 600 nurses working in a training and research Hospital in Ankara. The research group consisted of 451 nurses who reached and agreed to participate in the study. Questionnaire form was used as data collection tool. Frequency, percentage, Mann-Whitney U test, Kruskall-Wallis tests were used in the analysis of the data. The significance level was accepted as $\mathrm{p}<0.05$ in the study. Results: The average age of the nurses included in the study is $30.8 \pm 5.5$. It was determined that $54.6 \%$ of the nurses were single, $94.4 \%$ received undergraduate and above education, $87.1 \%$ worked as service nurses. It was determined that $57.7 \%$ of the nurses received information about genetics, $81.6 \%$ consider the developments in genetic science important, and $32.6 \%$ did not find genetic counseling services enough in our country. In our study, it was determined that the mean scores of the nurses' genetic knowledge test were $8.25 \pm$ $2.65(\min =0, \max =13)$ and the average genetic diseases knowledge test score was $6.52 \pm 1.83(\min =0, \max =10)$. According to the analysis, it was determined that those who care about the developments in genetic science, who use genetic information in the patient evaluation form, those who do not find the existing genetic counseling services sufficient, and those who want to do genetic counseling have higher mean scores on genetic and genetic diseases. It was found that the average score of genetic diseases knowledge was higher in nurses with a high level of education, and the average score of genetic knowledge was higher in nurses who had intensive care experience and were working in managerial positions. Conclusion: As a result of the research, it was determined that the awareness and competencies of nurses regarding their genetic counseling roles were not enough. It is recommended to make nurses competent with pre and post graduate training programs and to carry out further studies on the subject.

Keywords: Counseling, nursing, genetics, competence

Geliş Tarihi: 24.09.2020 Kabul Tarihi:08.11.2020

âGATA Eğitim ve Araştırma Hastanesi, Ankara, Türkiye, e-posta: yesyesot@ hotmail.com ORCID: 0000-0001-8617-1174

bYıldırım Beyazıt Üniversitesi Sağlık Bilimleri Fakültesi, Hemșirelik Bölümü, Ankara, Türkiye, e-posta: gpinar_1@ hotmail.com ORCID: 0000-00026952-6241

Sorumlu Yazar/Correspondence: Gül Pınar Calıșma yüksek lisans tezinden türetilmistir.

e-mail: gpinar_1@ @otmail.com

Atıf: Arslantürk Y, Pınar G. Hemşirelerin genetik danışmanlık rollerine ilişkin farkındalık ve yetkinliklerinin belirlenmesi. Sağlık ve Yaşam Bilimleri Dergisi 2020;2(2):49-56

Citation: Arslanturk Y, Pinar G. Determining awareness and competency of nurses regarding genetic counseling roles. Journal of Health and Life Science 2020;2(2):49-56. 


\section{GíRiş}

Dünyada kalıtsal hastalıkların artmasıyla birlikte genetik bilimi önem kazanmış, insan genom dizilenmesini takiben özellikle yetişkin yaşlardaki bireylere yönelik kanser tarama, diyabet hastalığına yatkınlık, prenatal ve pre-implantasyon tanı yöntemleri gibi çok sayıda yeni tanı testleri kullanılmaya başlanmıştır. ${ }^{1}$ İnsan genomu projesi kapsamında ivme kazanan gelişmeler; hastalıktan korunma, hastalıkları önleme ve hastalıkların tanı ile tedavisine önemli katkılar sağlamış, günümüzdeki sağlık anlayışının, klinik eğitim-danışmanlık, bakım ve sevk gibi hizmet sunumlarında da sağlık çalışanlarına yeni roller yüklemiştir. $^{3}$ Özellikle kalıtım nedenli onkolojik vakalar açısından açısından risk altındaki birey ve aileleri belirlenebilmekte, planlanmış eğitim ve danışmanlık hizmetleriyle bireylerin risk azaltıcı davranış geliştirmelerine olanak sağlanmaktadır. Ayrica, gastroenteroloji ya da prenatal taramalar; amniyosentez, kordosentez, koryonik villus biyopsisi (CVS) gibi prenatal tanı yöntemleri ile toplumda sıklıkla rastlanan kalıtsal hastalıklar gebeliğin erken dönemlerinde belirlenebilmektedir. Pre-implantasyon genetik tanı yöntemi ile de kalıtsal hastalıklar yönünden risk taşıyan ailelerde embriyolar genetik yönden incelenerek, sağlıklı embriyolar anneye transfer edilebilmektedir. Böylece genetik hastalık taşımayan, sağlıklı bebeklerin dünyaya gelmesi sağlanmaktadır. ${ }^{4-6}$

Son yıllarda yapılan genetik çalışmaların ve genetik hastalık tanılarının artması, ülkemizde akraba evliliklerinin oranının batı ülkelerine göre daha yüksek olması ve buna bağlı hastalıkların daha çok görülmesi, yapılan genom ve moleküler çalışmalar sonucunda, genetik geçişli hastalıklara erken dönemlerde tanı konulması genetik danışmanlığın önemini artırmaktadır. $1,4,7$

Ülkemizde genetik alanında verilen tedavi ve danışmanlık hizmetlerinde hekimler aktif rol alırken, uzmanlık gerektiren bu alana ilişkin bilgili ve deneyimli olmaları görev tanımları arasında yer almasına rağmen hemşirelerin danışmanlık rollerini kullanmada aktif rol almadıkları ve uzmanlaşmaya gidemedikleri görülmektedir., ${ }^{1,8} \mathrm{Bu}$ kapsamda çalışmada hemşirelerin genetik danışmanlık rollerine ilişkin farkındalıkları ve genetik risk değerlendirmedeki yetkinliklerinin belirlenmesi amaçlanmıştır. $\mathrm{Bu}$ bakımdan çalışmanın genetik alanında hemşirelik hizmetlerinin planlanmasında bir rehber olması ve literatüre katkı sağlaması beklenmektedir.

\section{YÖNTEM}

Araştırma, hemşirelerin genetik danışmanlık rolleri ve yetkinliklerine ilişkin farkındalıklarının belirlenmesi amaciyla, 1 Mart-30 Aralı 2014 tarihleri arasında yapılmış, tanımlayıcı bir araştırmadır. Araştırmanın evrenini Ankara'da bulunan bir eğitim ve araştırma hastanesinde çalışan hemşireler oluşturdu ( $n=600)$. Araştırmada örneklem seçimine gidilmedi, hastane bünyesinde çalışan tüm hemşirelerin araştırmaya katılması amaçlandı. Araştırmaya katılmayı kabul etmeme $(n=80)$, raporlu $(n=10)$, doğum izninde olma $(n=14)$ ve ön uygulamaya katılma $(n=45)$ nedenlerinden dolayı çalışma kapsamında 451 hemşireye (\%75) ulaşıldı.

Veri toplama aracı olarak, araştırmacı tarafindan literatür incelemesi sonrasında geliştirilen anket formu kullanıldı. Anket formu dört bölümden oluşmaktadır. Birinci bölümde; hemşirelerin sosyo-demografik özelliklerini belirlemeye yönelik sorular (7 madde) bulunmaktadır. İkinci bölümde; hemşirelerin genetik hastalıklar ve genetik danışmanlıkla ilgili eğitim alıp almadığına, genetik konusunda bilgi kaynaklarına, genetik bilimindeki gelişmeleri önemseme durumuna, genetik danışmanlık rolünü kullanma durumuna, genetik danışmanlığın kimler tarafından verilmesi gerektiğine, ülkemizdeki Genetik Danışmanlık Hizmetleri (GDH)'nin yeterli olup olmadığına, GDH'nin gelişmesine yönelik önerilerine, genetik yönden risk altındaki bireylerin değerlendirilmesine, genetik hastalık riskini belirlemek için hangi tarama programlarının düzenlenmesi gerektiğine yönelik sorular (15 madde) yer aldı. Üçüncü bölümde; hemşirelerin temel genetik alanındaki yetkinliklerini belirlemek amacıyla geliştirilen bilgi testine ait sorular (13 madde) bulundu. Genetik bilgi testinde her bir soru maddesine verilen doğru cevap " 1 " puan üzerinden değerlendirilmiş olup, bilgi testi toplam "13" puan üzerinden hesaplandı. Dördüncü bölümde; hemşirelerin genetik hastalıklar konusundaki yetkinliklerini belirlemek amacıyla geliştirilen genetik hastalıklar bilgi testine ait sorular (10 madde) yer aldi. Bilgi testinde her bir soru maddesine verilen doğru cevap " 1 ” puan üzerinden değerlendirilmiş olup, bilgi testi toplam " 10 " puan üzerinden hesapland1.

Çalışmanın ön uygulaması araştırma kriterlerine uygun örneklemin \%10'unu temsil eden 45 hemşire üzerinde yapılmış, veri toplama formunda yer alan soruların anlaşılabilir olduğu konusunda geri bildirim alındı ve anketin 15 ve 18. sorularına "En önemli üç öneriniz nedir?" ifadesi eklendi. Ön uygulama kapsamına alınan hemşireler çalışma örneklemine dahil edilmemiştir. Veri toplama araçları araştırmacı tarafından yüz yüze görüşülerek toplandı. Katılımcıların birbirleriyle etkileşimini önlemek için görüşmeler ayrı odada yapild1.

Veri toplama formu ile elde edilen bilgiler bilgisayar ortamına aktarıldı ve gerekli hata kontrolleri ve düzeltmeler yapıldı. Elde edilen veriler Lisanslı SPSS 
20.0 paket programı ile değerlendirildi. Verilerin normallik testleri sonucunda frekans, yüzde, iki gruplu karşılaştırmalarda Mann-Whitney U testi, 3 ve daha fazla gruplu karşılaştırmalarda Kruskall-Wallis testi kullanıldı. Çalışmada anlamlılık düzeyi $\mathrm{p}<0.05$ olarak kabul edildi.

Araştırmanın uygulanabilmesi için GATA Etik ve Anket Kurulundan izin alınmıştır. Araştırmaya katılımda gönüllülük esas alınmış ve katılmayı kabul eden hemşirelerle görüşme öncesi araştırmanın amacı, araştırmada sağlanacak yararlılıklar, görüşme için harcayacağı zaman ve yapması gerekenler konusunda açıklama yapılmış olup, yazılı onamları alınmıştır.

\section{BULGULAR}

Araştırmaya katılan hemşirelerin yaş ortalamasının $30.8 \pm 5.5 \quad(\min =20, \quad \max =50)$ olduğu, \%54.6'sının bekar, \%94.4'ünün lisans mezunu olduğu görülmüştür. Katılımcıların çalışma statülerine bakıldığında \%65.4'ünün servis hemşiresi olarak görev yaptığı ve $\% 44.8$ 'inin beş yıldan daha az süre çalıştığı tespit edilmiştir.

Hemşirelerin genetik konusunda bilgi alma durumu ve dağılımlarına bakıldığında; \%57.7'sinin genetik konusunda mesleki yaşamının herhangi bir döneminde bilgiye ulaştığı, \%88.5'inin mezuniyet öncesi eğitimden, \%74.7'sinin internetten bilgiye ulaştı̆̆1, \%81.6'sının genetik bilimindeki gelişmeleri önemsediği belirlenmiştir. Hemşirelerin genetik danışmanlık yapma durumuna ilişkin görüşleri incelendiğinde; \%99.1'inin geçmişte genetik danışmanlık yapmadığı ve \%72.8'inin GDH'yi yapmayı istemediği, \%37.9'u GDH'nin tıbbi genetik uzmanları, \%31.3'ü hemşireler tarafından verilmesi gerektiğini ifade ettiği görülmüştür. GDH'nin kimlere verilmesi gerekir sorusuna ise hemşirelerin \%13.7'si akraba evliliği yapanlara, \%13'ü ailede kalıtsal hastalığı bulunanlara verilmesi gerektiğini belirtmiştir.

Hemşirelerin GDH'ye ilişkin görüşleri incelendiğinde; \%19.1'i GDH verilmesi için hastalığa dair her şeyin bilinmesi gerektiğini, \%18.2'si etik kuralların bilinmesi gerektiğini belirtirken, \%32.6's1 ülkemizde GDH'nin yeterli düzeyde verilmediğini ifade etmiştir. Hemşirelerin GDH'yi yeterli bulmama nedenleri incelendiğinde, ilk sırada (\%20.8) hizmet alınacak yerlerin bilinmediği, ikinci sırada (\%16.4) toplumun ilgisizliği ve üçüncü olarak ise (\%12) politikaların yetersizliği yer almıştır. Hemşirelerin GDH'nin iyileştirilmesine yönelik önerileri incelendiğinde \%18.4'ünün evlilik öncesi danışmanlığın yapılması gerektiğini, \%17.6'sının lisans müfredatına entegre edilmesi gerektiğini ve \%17.1'inin ise hemşirelikte branşlaşmanın olması gerektiğini belirttiği görülmüştür.

$\underline{\text { Tablo 1. Hemşirelerin genetik bilgi testine verdikleri cevapların dağılımı }}$

\begin{tabular}{|c|c|c|c|c|}
\hline \multirow[b]{2}{*}{ Soru maddeleri (cevap anahtarı) } & \multicolumn{2}{|c|}{ Doğru } & \multicolumn{2}{|c|}{ Yanlış } \\
\hline & $\mathrm{n}$ & $\% *$ & $\mathrm{n}$ & $\% *$ \\
\hline Hücre çekirdeği içindeki kalıtsal maddedir (kromozom) & 84 & 18.6 & 367 & 81.4 \\
\hline Kalıtımın temel fiziksel ve işlevsel birimidir (gen) & 69 & 15.3 & 382 & 84.7 \\
\hline Bir organizmanın gözlenen yapısıdır (fenotip) & 214 & 47.4 & 237 & 52.6 \\
\hline Bir organizmanın genetik yapısıdır (genotip) & 223 & 49.4 & 228 & 50.6 \\
\hline Bireyin kromozom sayısı, şekli ve büyüklüğünü ifade eder (karyotip) & 365 & 80.9 & 86 & 19.0 \\
\hline Genlerin yapısı ve sayısındaki değişiklikler için kullanılır (mutasyon) & 169 & 37.4 & 282 & 62.5 \\
\hline Kendini eşlemiş kromozomun her bir parçasıdır (kromatid) & 170 & 37.6 & 281 & 62.3 \\
\hline Genetik özelliklerin akrabalar arasındaki dağılışını gösterir (mutasyon) & 400 & 88.6 & 51 & 11.3 \\
\hline $\begin{array}{l}\text { Vücut sıvısında fenilalanin birikmesi sonucu zeka geriliği ve erken yaşta ölüme } \\
\text { neden olur (fenilketonüri) }\end{array}$ & 410 & 90.9 & 41 & 9.0 \\
\hline $\begin{array}{l}\text { Ülkemizde özellikle Akdeniz Bölgesinde çok sık görülen bir anemi türüdür } \\
\text { (Akdeniz anemisi) }\end{array}$ & 417 & 92.4 & 34 & 7.5 \\
\hline $\begin{array}{l}\text { Edward Sendromu olarak ta bilinir ve bu bebeklerde kafa küçük, gözler aşağ1 } \\
\text { yerleşimli, küçük çene görünümü vardır (trizomi 18) }\end{array}$ & 392 & 86.9 & 59 & 13.0 \\
\hline $\begin{array}{l}\text { Hamileliğin ilk aylarında, beyin ve omuriliğin gelişimimi sırasında ortaya çıkan bir } \\
\text { bozukluktur (nöral tüp defekti) }\end{array}$ & 402 & 89.1 & 49 & 10.9 \\
\hline $\begin{array}{l}\text { Down Sendromu olarak bilinir, genelde üçlü tarama testi ile tanı konulur } \\
\text { (trizomi 21) }\end{array}$ & 405 & 89.8 & 46 & 10.2 \\
\hline
\end{tabular}

Tablo 1'de hemşirelerin \%92.4'ünün “Ülkemizde özellikle Akdeniz Bölgesinde çok sık görülen bir anemi türüdür" ifadesi ile akdeniz anemisini, \%90.9'unun "Vücut sıvisında fenilalanin birikmesi sonucu zeka geriliği ve erken yaşta ölüme neden olur" ifadesi ile fenilketonüriyi, \%89.8'inin "Down Sendromu olarak bilinir, genelde üçlü tarama testi ile tanı konulur" ifadesi ile trizomi 21 terimini, \%89.1'inin "Hamileliğin ilk aylarında, beyin ve omuriliğin gelişimi sırasında ortaya çıkan bir bozukluktur" ifadesi ile nöral tüp defekti terimini, \%88.6'sının "Genetik özelliklerin akrabalar arasındaki dağılışını gösterir" ifadesi ile soyağacı terimini, \%86.9'unun "Edward Sendromu olarak ta bilinir ve bu bebeklerde kafa küçük, gözler aşağı yerleşimli, küçük çene görünümü vardır" ifadesi ile trizomi 18 terimini, \%80.9'unun "Bireyin kromozom sayısı, şekli ve büyüklüğünü ifade 
eder" ifadesi ile karyotip terimini doğru eşleştirdikleri

belirlenmiştir.

Tablo 2. Hemşirelerin genetik hastalıklara ilişkin bilgi testine verdikleri cevapların dağılımı

\begin{tabular}{|c|c|c|c|c|}
\hline \multirow[b]{2}{*}{ Soru maddeleri (cevap anahtarı) } & \multicolumn{2}{|c|}{ Doğru } & \multicolumn{2}{|c|}{ Yanlış } \\
\hline & n & $\% *$ & n & $\% *$ \\
\hline Gen haritasının çıkarılmasıyla bazı kanserlerin erken tanısı mümkün olabilmektedir (D) & 435 & 96.3 & 16 & 3.7 \\
\hline $\begin{array}{l}\text { Mendel kanunlarına göre kalıtsal faktörler hiçbir zaman kendi özelliklerini yitirmeyip, } \\
\text { bir sonraki kuşağa bir değişikliğe uğramadan ortaya çıkmaktadır (D) }\end{array}$ & 324 & 71.7 & 127 & 28.3 \\
\hline $\begin{array}{l}\text { Kromozom anomalileri, kromozomların eksik, fazla veya anormal düzenlenmesi } \\
\text { sonucu oluşur (D) }\end{array}$ & 426 & 94.5 & 25 & 5.5 \\
\hline Genetik hastalığın çocuklarda yineleme riski yoktur $(\mathrm{Y})$ & 187 & 41.5 & 264 & 58.5 \\
\hline Hemofili, X'e bağlı resesif geçiş gösteren doğumsal bir kanama bozukluğudur (D) & 329 & 72.0 & 122 & 27.0 \\
\hline $\begin{array}{l}\text { BRCA1 veya BRCA2 gen mutasyonu ile kalıtsal meme ve over kanseri arasında ilişki } \\
\text { vardır (D) }\end{array}$ & 294 & 65.2 & 157 & 34.8 \\
\hline Otozomal kromozomlar 44 çift, cinsiyet kromozomlar 2 çifttir (D) & 348 & 77.2 & 103 & 22.8 \\
\hline Kromozom analizi normal olan çiftlerin embriyolarında genetik hastalık görülmez (Y) & 160 & 35.5 & 291 & 64.5 \\
\hline $\mathrm{X}$ kromozomuna bağlı kalıtım hastalığı taşıyıcı anneden oğla geçer $(\mathrm{Y})$ & 94 & 20.8 & 357 & 79.2 \\
\hline $\begin{array}{l}\text { Onkogen, kontrolünü kaybetmiş protein kodlayan genlerdir ve kanser gelişiminin } \\
\text { başlangıcında rol oynar (D) }\end{array}$ & 344 & 76.3 & 107 & 23.7 \\
\hline
\end{tabular}

*Satır yüzdesi alınmıştır.

Tablo 3. Hemşirelerin sosyo-demografik özellikleri ve genetik danışmanlık rolleri ile yetkinliklerine göre Genetik Bilgi Testi (GBT) puan ortalamalarının dağılımı

\begin{tabular}{|c|c|c|c|c|c|c|c|}
\hline Sosyo-demografik özellikler & & & GBT & $\mathrm{SS}=8.2$ & $\min =($ & $=13)$ & Analiz* \\
\hline Yaş & $\mathbf{N}$ & Mean & Min & Max & SS & Sira .Ort. & \\
\hline $\begin{array}{l}20-25 \\
26-30 \\
31-35 \\
35 \text { yaş üzeri }\end{array}$ & $\begin{array}{r}82 \\
153 \\
114 \\
102\end{array}$ & $\begin{array}{l}8.74 \\
8.28 \\
8.18 \\
7.92\end{array}$ & $\begin{array}{l}0 \\
0 \\
1 \\
0\end{array}$ & $\begin{array}{l}13 \\
13 \\
13 \\
13 \\
\end{array}$ & $\begin{array}{l}3.05 \\
2.55 \\
2.36 \\
2.75\end{array}$ & $\begin{array}{l}255.21 \\
222.11 \\
225.51 \\
208.90\end{array}$ & $\begin{array}{c}x^{2}=6.381 \\
p=0.094\end{array}$ \\
\hline $\begin{array}{l}\text { Medeni durum } \\
\text { Evli } \\
\text { Bekar } \\
\end{array}$ & $\begin{array}{l}196 \\
255 \\
\end{array}$ & $\begin{array}{l}8.5 \\
8.1 \\
\end{array}$ & $\begin{array}{l}0 \\
0 \\
\end{array}$ & $\begin{array}{l}13 \\
13 \\
\end{array}$ & $\begin{array}{l}2.8 \\
2.5 \\
\end{array}$ & $\begin{array}{l}238.76 \\
213.55 \\
\end{array}$ & $\begin{array}{l}Z=-1.88 \\
p=0.060\end{array}$ \\
\hline $\begin{array}{l}\text { Ĕgitim durumu } \\
\text { Ön lisans ve altı } \\
\text { Lisans ve üzeri }\end{array}$ & $\begin{array}{r}25 \\
426 \\
\end{array}$ & $\begin{array}{l}5.24 \\
6.55 \\
\end{array}$ & $\begin{array}{l}0 \\
3 \\
\end{array}$ & $\begin{array}{r}9 \\
10 \\
\end{array}$ & $\begin{array}{l}0.40 \\
0.19 \\
\end{array}$ & $\begin{array}{l}138.48 \\
245.79\end{array}$ & $\begin{array}{c}\mathrm{U}=13.558 \\
\mathbf{p}=\mathbf{0 . 0 0 1}\end{array}$ \\
\hline $\begin{array}{l}\text { Genetik eğitimi alma durumu } \\
\text { Evet } \\
\text { Hayır } \\
\text { Hatırlamıyorum } \\
\end{array}$ & $\begin{array}{r}260 \\
137 \\
54 \\
\end{array}$ & $\begin{array}{l}8.5 \\
8.2 \\
7.7 \\
\end{array}$ & $\begin{array}{l}0 \\
0 \\
0 \\
\end{array}$ & $\begin{array}{l}13 \\
13 \\
13 \\
\end{array}$ & $\begin{array}{l}2.4 \\
3.1 \\
2.7 \\
\end{array}$ & $\begin{array}{l}222.1 \\
242.7 \\
202.3 \\
\end{array}$ & $\begin{array}{l}x^{2}=4.53 \\
p=0.104\end{array}$ \\
\hline
\end{tabular}

*Ki-Kare testi, Kruskal-Wallis testi, Mann-Whitney U Testi

Tablo 2'de hemşirelerin \%96.3'ünün “Gen haritasının çıkarılmasıyla bazı kanserlerin erken tanısı mümkün olabilmektedir" ifadesine, \%94.5'i “Kromozom anomalileri, kromozomların eksik, fazla veya anormal düzenlenmesi sonucu oluşur" ifadesine, \%77.2'si "Otozomal kromozomlar 44 çift, cinsiyet kromozomlar 2 çifttir” ifadesine, \%76.3'ü “Onkogen, kontrolünü kaybetmiş protein kodlayan genlerdir ve kanser gelişiminin başlangıcında rol oynar" ifadesine, \%72'si "Hemofili, X'e bağlı resesif geçiş gösteren doğumsal bir kanama bozukluğudur" ifadesine, \%71.7'si "Mendel kanunlarına göre kalıtsal faktörler hiçbir zaman kendi özelliklerini yitirmeyip, bir sonraki kuşağa bir değişikliğe uğramadan ortaya çıkmaktadır" ifadesine, \%65.2'si “BRCA1 veya BRCA2 gen mutasyonu ile kalitsal meme ve over kanseri arasında ilişki vardır" ifadesine, \%41.5'i “Genetik hastalığın çocuklarda yineleme riski yoktur" ifadesine, \%35.5'i "Kromozom analizi normal olan çiftlerin embriyolarında genetik hastalık görülmez" ifadesine, \%20.8'i "X kromozomuna bağlı kalıtım hastalığı taşıyıcı anneden oğula geçer" ifadesine doğru yanıt verdikleri belirlenmiştir. Tablo 3 'te hemşirelerin GBT puan ortalamalarının $8.2 \pm 2.6$ ( $\min =0, \max =13)$ olduğu görülmüştür. Hemşirelerin yaşları ve meslekte çalışma süreleri arttıkça GBT puan ortalamalarının azaldığı görülmekle birlikte aralarında anlamlı bir farklılık bulunmamaktadır ( $p>0.01)$. Evli olan ve genetik eğitim alan hemşirelerin GBT puan ortalamaları daha yüksek olmakla birlikte aralarında istatistiksel olarak anlamlı bir farklılık bulunmamıştır $(\mathrm{p}>0.01)$. Ancak, eğitim düzeyi yükseldikçe bilgi puanlarının arttığı ve 
istatistiksel olarak anlamlı olduğu bulunmuştur $(\mathrm{p}<0.05)$. Tablo 4'de hemşirelerin çalıştıkları birim, çalışma statüleri, genetik bilimindeki gelişmeleri önemseme durumu, genetik danışmanlık hizmeti vermeyi isteme durumu, genetik danışmanlık hizmetini yeterli bulma durumu, hasta veri toplama formunda genetik ile ilgili sorulara yer verilme durumuna göre GBT puan ortalamaları arasında istatistiksel olarak anlamlı bir fark bulunduğu belirlenmiştir $(\mathrm{p}<0.05)$.

Tablo 4. Hemşirelerin mesleki özellikleri ve genetik danışmanlık rolleri ile yetkinliklerine göre Genetik Bilgi Testi (GBT) puanlarının dağılımı

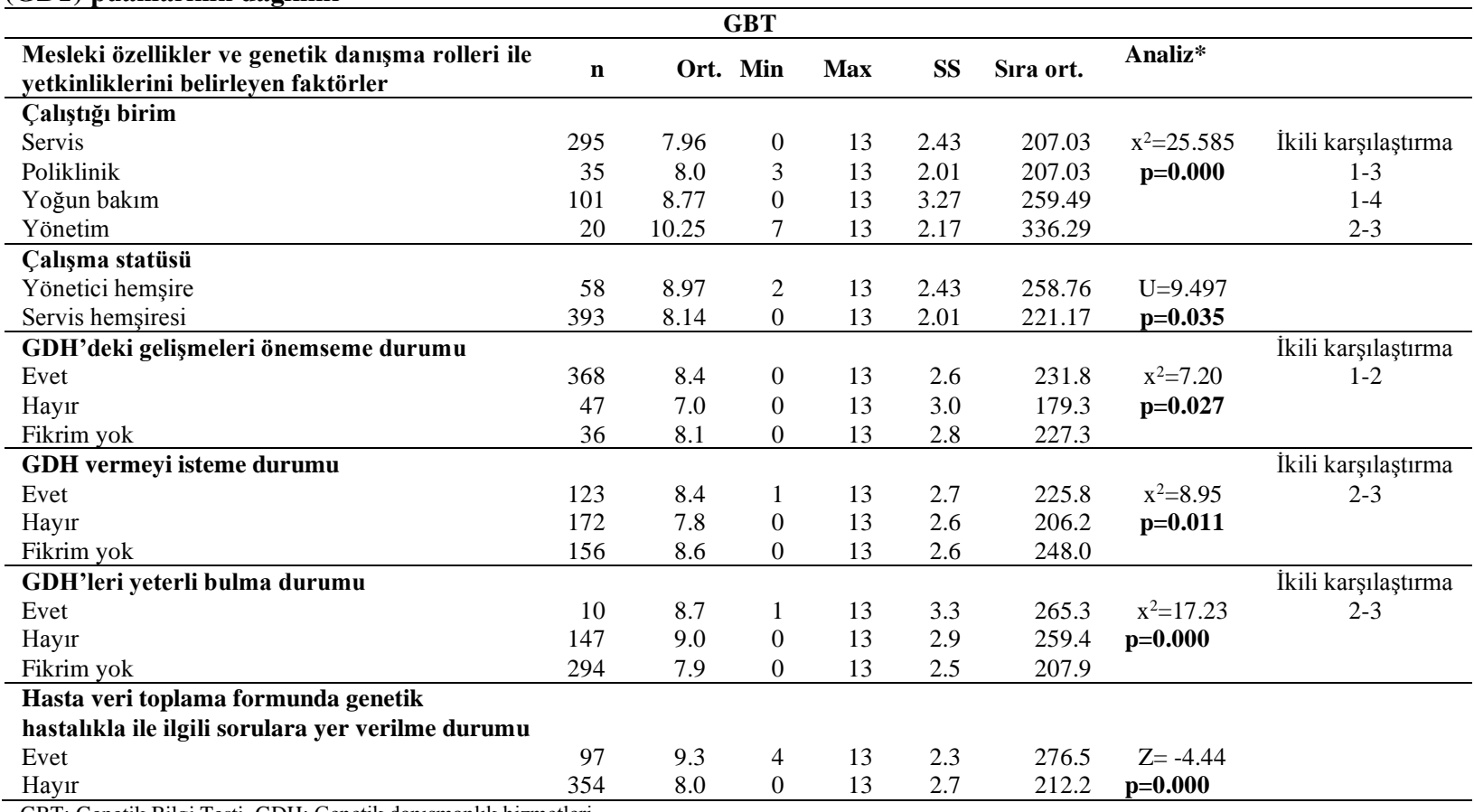

GBT: Genetik Bilgi Testi, GDH: Genetik danısmanlik hizmetleri

*Ki-Kare testi, Mann Whitney U testi ve Kruskal Wallis testi kullanılmıştır ( $\mathrm{p}<0.05$ ).

Tablo 5. Hemşirelerin mesleki özellikleri ve genetik danışmanlık rolleri ile yetkinliklerine göre Genetik Hastalıklar Bilgi Testi (GHBT) Puanlarının dağılımı

\begin{tabular}{|c|c|c|c|c|c|c|c|c|}
\hline \multirow{2}{*}{$\begin{array}{l}\text { Mesleki özellikler ve genetik danışma rolleri } \\
\text { ile yetkinliklerini belirleyen faktörler }\end{array}$} & \multicolumn{7}{|c|}{ GHBT $(6.52 \pm 1.83 ; \min =0, \max =10)$} & \\
\hline & $\mathbf{N}$ & Ort. & Min & $\begin{array}{l}\mathbf{M} \\
\mathbf{a x}\end{array}$ & SS & $\begin{array}{l}\text { Sira } \\
\text { ort. }\end{array}$ & Analiz & \\
\hline \multicolumn{9}{|l|}{ Çalışma statüsü } \\
\hline Yönetici hemşire & 58 & 7.96 & 3 & 10 & 0.22 & 220.38 & \multirow{2}{*}{$\begin{array}{l}Z=9188.5^{*} \\
\mathbf{p}=\mathbf{0 . 0 1 5}\end{array}$} & \\
\hline Servis hemşiresi & 393 & 6.43 & 0 & 10 & 0.09 & 264.08 & & \\
\hline \multicolumn{9}{|l|}{ Eğitim alma durumu } \\
\hline Evet & 260 & 6.89 & 2 & 10 & 0,10 & 247.9 & \multirow{3}{*}{$\begin{array}{c}\mathrm{X}^{2}=18.152 * \\
\mathbf{p}=\mathbf{0 . 0 0 1}\end{array}$} & İkili karşılaştırma \\
\hline Hayır & 137 & 5.97 & 0 & 10 & 0,18 & 193.88 & & $1-2$ \\
\hline Hatırlamiyorum & 54 & 5.64 & 0 & 9 & 0,26 & 201.91 & & $1-3$ \\
\hline \multicolumn{9}{|l|}{ GDH vermeyi isteme durumu } \\
\hline Evet & 123 & 6.89 & 3 & 10 & 0,14 & 249.13 & \multirow{3}{*}{$\begin{array}{l}x^{2}=6.797 * \\
\mathbf{p}=\mathbf{0 . 0 3 3}\end{array}$} & İkili karşılaştırma \\
\hline Hayır & 172 & 6.27 & 0 & 10 & 0,15 & 209.7 & & $1-2$ \\
\hline Fikrim yok & 156 & 6.51 & 0 & 10 & 0,14 & 225.74 & & \\
\hline \multicolumn{9}{|l|}{ GDH'lerini yeterli bulma durumu } \\
\hline Evet & 10 & 5.30 & 3 & 7 & 0.45 & 130.3 & \multirow{3}{*}{$\begin{array}{l}x^{2}=25.622 * \\
\mathbf{p}=\mathbf{0 . 0 0 1}\end{array}$} & İkili karşılaştırma \\
\hline Hayır & 147 & 7.06 & 0 & 10 & 0.14 & 266.66 & & $1-2$ \\
\hline Fikrim yok & 294 & 6.29 & 0 & 10 & 0.11 & 208.93 & & $2-3$ \\
\hline \multicolumn{9}{|l|}{$\begin{array}{l}\text { Hasta veri toplama formunda genetik ile } \\
\text { ilgili sorular }\end{array}$} \\
\hline Var & 97 & 6.92 & 3 & 10 & 0.15 & 250.85 & \multirow{2}{*}{\multicolumn{2}{|c|}{$\begin{array}{l}Z=14759 * * \\
\mathbf{p}=\mathbf{0 . 0 3 1}\end{array}$}} \\
\hline Yok & 354 & 6.41 & 0 & 10 & 0.10 & 219.19 & & \\
\hline
\end{tabular}

GHBT; Genetik Hastalıklar Bilgi Testi, GDH: Genetik danışmanlık hizmetleri, *Ki-Kare testi ve Kruskal Wallis testi kullanılmıştır (p<0.05).

Tablo 5'te hemşirelerin GHBT puanlarının $6.5 \pm 1.8$ ( $\min =0, \max =10)$ olduğu görülmüştür. Hemşirelerin eğitim alma durumu, çalışma statüleri, genetik bilimindeki gelişmeleri önemseme durumu, genetik danışmanlık hizmeti vermeyi isteme durumu, genetik danışmanlık hizmetini yeterli bulma durumu, hasta veri toplama formunda genetik ile ilgili sorulara yer verilme durumuna ile genetik hastalık bilgi testi puan ortalamaları arasında istatistiksel olarak anlamlı bir fark tespit edilmiştir $(\mathrm{p}<0.05)$. 
Tabloda olmamakla birlikte, hemşirelerin eğitim düzeyi ön lisans ve altı olan hemşirelerin GHBT puan ortalamaları $5.2 \pm 0.4$ iken, lisans ve üzeri olan hemşirelerin $6.5 \pm 0.1$ olduğu görülmüştür. Bu bulguya göre eğitim düzeyi yükseldikçe bilgi puan ortalaması da artmaktadır $(\mathrm{U}=13.55, \mathrm{p}=0.001)$.

\section{TARTIŞMA}

Araştırmamızda hemşirelerin yarıdan fazlası mesleki yaşamlarının herhangi bir döneminde genetik konusunda bilgi aldıklarını ifade etmişlerdir. Genetik konusunda hemşirelerin bilgi kaynakları incelendiğinde, sırasıyla mesleki eğitimde (\%88.5), internet (\%74.7) ve medya-televizyon (\%46.2) yoluyla bu bilgiye ulaşıldığı belirtilmiştir. Yapılan çalışmalar incelendiğinde, Kim'in Seul'de on bir hastanede çalışan hemşirelerle yaptığı çalışmada, genetik alanında \%54.9'unun bilgi kaynağı olarak kitle iletişim araçlarını kullandıkları9, Godino ve arkadaşlarının çalışmasında hemşirelerin genetik konusunda bilgi kaynaklarını çoğunlukla medya kanalı ile elde ettikleri belirlenmiştir. $^{2}$ Turaçlar ve arkadaşlarının yaptığı çalışmada ise hemşirelik öğrencilerinin \%97.1'inin genetik bilgilerini lisans eğitiminde aldıklarını ve bu eğitim sırasında bu bilgileri \%64.4 çocuk sağlığı ve hastalıkları dersinden, \%61.7 doğum ve kadın sağlığı dersinden aldıkları tespit edilmiştir. ${ }^{10}$ Özkan ve Arslan'nın yaptığı çalışmada hemşirelik öğrencilerinin çoğunluğu eğitimleri boyunca genetikle ilgili bilgi edindiğini, ancak genetik danışmanlıkla ilgili bilgilerinin yetersiz olduğunu belirtmiştir. ${ }^{11}$ Çalışma bulgumuz yapılan çalışmalarla uyumlu olup, hemşirelerin genetik alanında almış oldukları mesleki eğitimin yanı sıra bilgiye ulaşmada kitle iletişim araçlarının da önemli olduğunu göstermektedir.

Araştırmamızda hemşirelerin büyük çoğunluğunun (\%81.6) genetik bilimindeki gelişmeleri önemsediğini belirtmesi sevindirici bir bulgudur. Daha önce yapılan bir çalışmada genetik alanında primer bakım veren sağlık personelinin \%95 gibi önemli bir bölümünün genetik ile ilgili gelişmeleri önemsediği tespit edilmiştir. $^{12} \mathrm{Bu}$ sonuç çalışma bulgumuzu desteklemekle birlikte hemşirelerin genetik alanındaki gelişmelere yönelik farkındalıklarının yüksek olduğunu göstermektedir. Çalışmamızda hemşirelerin hemen hemen tamamına yakını (\%99.1) mesleki yaşamlarında GDH vermediklerini belirtirken, \% 72.8'i genetik danışmanlık yapmayı istemediğini ifade etmiştir. Kim'in çalışmasında klinik hemşirelerinin sadece \%14.9'unun aktif olarak genetik danışmanlık yaptığı, \%34'ünün genetik danışmanlık yapmayı istemediği belirlenmiştir. ${ }^{9}$ Çalışmamızda hemşirelerin büyük çoğunluğunun GDH vermemeleri ve genetik danışmanlık yapmayı istememeleri dikkat çeken bir bulgudur. Literatürde, GDH klinik deneyimi olan doktor, hemşire, sosyal hizmet uzmanı, pediatri uzmanı, genetik uzmanı ve psikologdan oluşan bir ekip tarafından yapılması gerektiği vurgulanmaktadır. ${ }^{13}$
Literatüre göre birçok ülkede genetik danışmanlık hizmetleri; nöroloji, endokrinoloji, pediatri, onkoloji, tıbbı genetik uzmanları, laborant ve genetik hemşiresi ile oluşturulan bir ekip tarafından yürütüldüğü belirtilmektedir. ${ }^{1,4-7}$ Ülkemizde ise genetik alanında verilen sağlık hizmetlerinde ve GDH'ta özellikle hekimlerin aktif oldukları görülmektedir. Genellikle hasta ve hastalıklarla ilk karşılaşanlar birinci basamakta görevli hekimler ve pediatristler olduğundan genetik hastalıkların tespiti ve hastaların ilgili birimlere yönlendirmeleri bu aşamada yapılmaktadır. Ancak halen ülkemizde genetik hastalıkların erken dönemde tespit edilmesi ve uygun GDH'in verilmesi istenen düzeyde bulunmamaktadır. ${ }^{2,8,12}$

Araştırma kapsamında yer alan hemşirelerin \%32.6'sının ülkemizde verilen GDH'1 yeterli bulmadığı, \%65.1'inin ise bu konuda fikri olmadığı saptanmıştır. GDH'ın yeterli bulunmama sebeplerine bakıldığında, hemşirelerin \%20.8'i hizmet alınacak yerlerin bilinmediği, \%16.4'ü toplumun bu konuda ilgisiz olduğu, \%12'si politikaların yetersizliği olarak ifade etmiştir. Diğer bir çalışmada ise GDH'ın yetersiz bulunmasının sebepleri arasında halkın sağlık algısı ve sosyal destek arayışı, hastalıkla ilgili belirsizlik, bilginin nereden alınacağının bilinmemesi gibi faktörlerin rol oynadığı görülmüştür. ${ }^{14}$

Çalışmamızda hemşirelerin genetik danışmanlığın iyileştirilmesine yönelik önerileri incelendiğinde, $\%$ 18.4'ü evlilik öncesi danışmanlık yapılması, \%17.6'sı lisans eğitiminde genetik hastalıklar ve genetik danışmanlık konularının daha kapsamlı yer alması, \%17.1'i hemşirelikte branşlaşmanın olması gerektiğini belirtmiştir. ABD ve Kanada'da genetik danışmanlık konusunda sertifika ve özel eğitim programları düzenlenmekte, yüksek lisans ve doktora eğitimleri bulunmaktadır. ${ }^{15,16}$ Yurt dışında genetik eğitiminin içeriğinin tanımlanmasında rehber olan, profesyonel hemşirelik kuruluşları tarafından klinikte çalışan hemşirelere yol gösterici olabilmesi için 2001 yılında Uluslararası Genetik Hemşireleri Derneği (ISONG) kurulmuştur. ${ }^{3} \mathrm{Bu}$ derneğe üye birçok ülke bulunmasına rağmen, Türkiye'nin bu üyeler arasında yer almaması üzücü bir durumdur. ${ }^{17-20}$

Fenilketonüri ve down sendromu gibi genetik geçişli hastalıklar ülkemizde yaygın görülmektedir. Sağlık çalışanlarının genetik hastalıkların önlenmesi ve erken tespitinde danışmanlık rolleri büyük önem taşımaktadır. ${ }^{20}$ Çalışmamızda hemşirelerin GBT puan ortalamaları $8.2 \pm 2.6$ olarak belirlenmiştir. $\mathrm{Bu}$ bulgu hemşirelerin temel genetik alanında yetkinliklerinin göreceli olarak yeterli olduğunu, ancak geliştirilmesi gerektiğini ortaya koymaktadır. Nitekim özellikle GDH'nin evlilik öncesi, prekonsepsiyonel, gebelik ve doğum sonu dönemlerde verilmesi önem taşımaktadır. Çalışmamızda hemşirelerin GHBT puan ortalamalarının $6.5 \pm 1.8$ olduğu belirlenmiştir. $\mathrm{Bu}$ 
bulgu, bilgi testinde yer alan genetik hastalıklara yönelik 10 sorudan ortalama altısına doğru yanıt verildiğini göstermektedir. $\mathrm{Bu}$ bulguya göre hemşirelerin genetik hastalıklar bilgi testinde yer alan soruların yarısından fazlasına doğru yanıt vermeleri, bu alandaki yetkinliklerinin yeterli olduğunu ancak desteklenmesi gerektiğini göstermektedir.

Hemşirelerin çalışma statüleri ile GBT puan ortalamaları karşılaştırıldığında, yönetici hemşirelerde bu ortalama $8.9 \pm 2.6$ iken, servis hemşirelerinde $8.1 \pm 2.6$ olduğu görülmüştür. $\mathrm{Bu}$ sonuçlara göre hemşirelerin çalışma statüleri ile GBT puan ortalamaları arasında istatistiksel olarak anlamlı bir fark olduğu belirlenmiştir. Kim'in çalışmasında, sorumlu hemşirelerin diğerlerine göre bilgi seviyelerinin daha yüksek olduğu (2.2 \pm 3.9$)$, klinik hemşirelerin bilgi seviyelerinin ise daha düşük olduğu

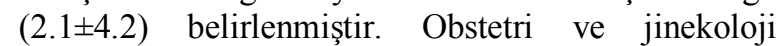
bölümünde çalışan hemşirelerin bilgi seviyesi daha yüksek iken $(2.3 \pm 3.3)$, yoğun bakımda çalışan

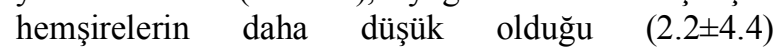
görülmüştür. ${ }^{9}$ Bu bulgu bizim çalışmamızla uyum göstermekte birlikte, yönetici ya da sorumlu hemşirelerin bilgi seviyelerinin diğer hemşirelerden daha yüksek olması beklenen durumdur. Genellikle yönetimde yer alan hemşirelerin eğitim seviyelerinin en az lisans mezunu olması, mevzuat ve yönetmelikler hakkında daha fazla bilgi sahibi olmaları sebebiyle farklılık göstermektedir. Araştırma bulgularımıza göre hemşirelerin GDH vermeyi isteme durumları ile temel genetik bilgi puan ortalamaları arasında istatistiksel olarak anlamlı bir farkın olduğu saptanmıştır. Kim'in çalışmasında GDH vermeyi isteyen hemşirelerin bilgi puanları $2.2 \pm 4.2$ iken, GDH vermeyi istemeyen hemşirelerin bilgi puanlarının $2.1 \pm 4.0$ olduğu ve GDH vermeyi isteyenlerin bilgi seviyesinin istemeyenlere göre daha yüksek olduğu belirlenmiştir. ${ }^{9}$ Araştırmamızda çalıştıkları birimde kullandıkları hasta veri toplama formunda genetik hastalıklar ile ilgili sorulara yer verildiğini belirten hemşirelerin bilgi puan ortalamaları $9.3 \pm 2.3$ iken, yer verilmediğini belirten hemşirelerin bilgi puan ortalamalarının $8.0 \pm 2.7$ olduğu görülmüştür. $\mathrm{Bu}$ sonuçlara göre hasta veri toplama formunda genetik hastalıklar ile ilgili sorulara yer verilme durumu ile temel genetik bilgi testi puan ortalamaları arasında anlamlı bir fark olduğu belirlenmiştir $(p<0.05)$. Çalışmamızın bu bulgusu, veri toplama formlarının standart hale gelmesinin ve içeriğinde genetik hastalıklar ile ilgili sorulara yer verilmesinin, hemşirelerin genetik alanında bilgi seviyelerinin ve farkındalıklarının daha fazla olduğunu göstermektedir.

Araştırmamızda hemşirelerin eğitim durumlarına göre GHBT puan ortalamaları incelendiğinde, eğitim düzeyi ön lisans ve altında eğitimi olanlarda $5.2 \pm 0.4$, eğitim düzeyi lisans ve üzeri eğitimi olanlarda ise $6.5 \pm 0.1$ olduğu saptanmıştır $\quad(p<0.05)$. Calzone ve arkadaşlarının hemşireler üzerinde yaptığı bir çalışmada, eğitim seviyesinin artmasıyla sorulara doğru yanıt verme oranının arttığı görülmüştür. Doktora eğitimi alan hemşirelerin sorulara doğru cevap verme oranı \%67.3 iken, yüksek lisans mezunu olanlarda bu oranın \%54.7 ve lisans mezunu olanlarda \%28.5 olduğu belirtilmiştir. ${ }^{19}$ Seven ve arkadaşları ve Thompson ve Brooks çalışmalarda da eğitim düzeyi yüksek olan hemşirelerin genetik bilgisinin daha yüksek olduğu tespit edilmişstir. ${ }^{8,13}$ Araştırma sonuçları çalışma bulgumuzu desteklemektedir. Eğitim düzeyi arttıkça bilgi seviyesinin artması hemşirelik lisans ve lisansüstü eğitiminin önemini ortaya koymaktadır.

Araştırmamızda hemşirelerin çalışma statüleri ile GHBT puan ortalamaları karşılaştırıldığında, yönetici hemşirelerin puan ortalamaları $7.1 \pm 0.2$ iken, servis hemşirelerinin $6.4 \pm 0.0$ olduğu görülmüştür. Genetik ile ilgili eğitim alma durumlarına göre GHBT puan ortalamaları incelendiğinde, daha önceden eğitim alanların puan ortalamaları $6.8 \pm 0.1$ iken, eğitim almayan hemşirelerin GHBT puan ortalamaları $5.9 \pm 0.1$ olduğu belirlenmiştir. Kim'in çalışmasında, sorumlu hemşirelerin diğerlerine göre bilgi seviyelerinin daha yüksek olduğu (2.2 \pm 3.9$)$, klinik hemşirelerin bilgi seviyelerinin ise daha düşük olduğu

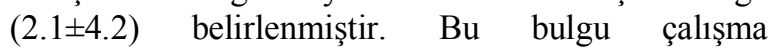
sonuçlarımızı desteklemekle birlikte yönetici hemşirelerin GHBT puan ortalamalarının yüksek olması beklenen bir durumdur. Godino ve arkadaşlarının İtalyan hemşirelerle yaptığı çalışmada, hemşirelerin daha önceden genetik konusunda eğitim alma durumları ile bilgi puanları arasında pozitif bir ilişki olduğu görülmüştür. ${ }^{20}$ Çalışma sonucu, araştırma bulgumuzu desteklemekte olup, eğitimin önemini vurgulamaktadır.

Çalışmamızda hemşirelerin genetik bilimindeki gelişmeleri önemseme durumuna göre GHBT puan ortalamalarına bakıldığında, genetik bilimindeki gelişmeleri önemseyenlerin GHBT puan ortalamalarının $6.7 \pm 0.1$ olduğu, önemsemeyenlerin ise $5.7 \pm 0.3$ olduğu saptanmıştır. Araştırmamızın bu bulgularına göre hemşirelerin genetik bilimindeki gelişmeleri önemsemeleri ile GHBT puan ortalamaları arasında anlamlı istatistiksel olarak bir farkın olduğu belirlenmiştir $(\mathrm{p}<0.05)$. Çalışmamızda genetik bilimindeki gelişmeleri önemseyen hemşirelerin GHBT puan ortalamalarının yüksek olması, bu konuda farkındalık oluşturmaları açısından önem taşımaktadır. Araştırmamızda hemşirelerin GDH vermeyi isteme durumları ile GHBT puan ortalamaları karşılaştırıldığında, GDH vermeyi isteyen hemşirelerin GHBT puan ortalamalarının $6.8 \pm 0.1$, istemeyenlerin ise $6.2 \pm 0.15$ olduğu görülmüştür. $\mathrm{Bu}$ bulgulara göre hemşirelerin GDH vermeyi isteme durumları ile GHBT puan ortalamaları arasında istatistiksel olarak anlamlı bir fark olduğu görülmüştür $(\mathrm{p}<0.05)$. Kim'in çalışmasında danışmanlık yapmayı isteyen hemşirelerin bilgi puanları $2.2 \pm 4.2$ iken, danışmanlık yapmayı istemeyen hemşirelerin bilgi puanlarının 
$2.1 \pm 4.0$ olduğu ve danışmanlık yapmayı isteyenlerin bilgi seviyesinin danışmanlık yapmayı istemeyenlere göre daha yüksek olduğu belirlenmiştir. ${ }^{9}$ Araştırma sonucu çalışma bulgumuzu desteklemektedir.

\section{SONUÇ}

Araştırma sonucunda, hemşirelerin genetik danışmanlık rollerine ilişkin farkındalıkları ile yetkinliklerinin yeterli olmadığı saptanmıştır. Hemşirelerin genetik danışmanlık rollerini daha iyi benimseyebilmeleri ve uygulayabilmeleri için mesleki yayınları takip etmeleri, araştırma ile ilgili kurslara katılmaları, kongre, sempozyum gibi bilimsel etkinliklerde rol almaları, mesleki dernek ve örgütlere üye olmaları önerilebilir. Hemşirelik lisans eğitimi programı kapsamında genetik konularına detaylı olarak yer verilmesi, bunun yanı sıra genetik hemşireliğin zorunlu ders olarak verilmesi bilgi ve farkındalığ artırabilir. Hemşirelere mezuniyet sonrası yüksek lisans ve sertifikalı eğitimlerle genetik hemşirelik alanında uzmanlaşma imkanın sağlanması önerilir. Aynı zamanda genetik hemşireliğin uzmanlık alanı olarak mevzuatta yer alması, görev, yetki ve sorumluluk tanımlarının yasal düzenlemelerle belirlenmesi önerilir. Genetik ile ilgili derneklerin sayısının artması ve bu derneklerde hemşirelerin aktif rol almaları önerilir. Hasta veri toplama formlarında genetik öyküye yönelik soruların yer alması ve bu formların standart hale getirilmesi önerilir. Hemşirelerin genetik danışmanlık rollerini ve farkındalıklarını kapsayan, ülke genelini ve farklı bölgeleri temsil edebilen bilimsel çalışmaların arttırılması ve araştırma sonuçlarının hizmete yansıtılması önerilir.

\section{KAYNAKLAR}

1. Dodson C. Knowledge and attitudes of oncology nurses regarding pharmacogenomics testing. Clin J Oncol Nurs. 2014;18(4): E64-70.

2. Godino L, Turchetti D, Skirton H. Genetic counseling: a survey to explore knowledge and attitudes of Italian nurses and midwives. Nurs Health Sci. 2013;15 (1):15-21.

3. International Society of Nurses in Genetics (ISONG). What is a genetic nurse. http://www.isong.org/ISONG_genetic_nurse.php. Erișim tarihi: 12.06.2015.

4. Jenkins J, Calzone KA. Establishing the essential nursing competencies for genetics and genomics. $J$ Nurs Scholar. 2007;39(1):10-6.

5. Skirton H, Cordier C, Lambert D, et al. A study of the practice of individual genetic counselors and genetic nurses in Europe, J.Community Genet. 2013;4(1):69-75.
6. Umberger R, Holston E, Hutson S, Pierce M. Nursing genomics, and practice implications every nurse should know. Nurs Clin N Am. 2013;48:499522.

7. Wevers MR, Ausems MG, Verhoef S., et al. Behavioral and psychosocial effects of rapid genetic counseling and testing in newly diagnosed breast cancer patients: Design of a multicenter randomized clinical trial. BMC Cancer. 2011;11(6):175-180.

8. Seven M, Akyüz A, Elbüken B, Skirton H, Öztürk H. Nurses's knowledge and educational needs regarding genetics. Nurs Educ Today. 2015; 35 (3):444-49.

9. Kim MY. The nurses' knowledge and perception of their role in genetics, Journal of Korean Acad of Nurs. 2003; 33(8):33-9.

10. Turaçlar N., Altuntuğ K., Ege E. Ebelik ve hemşirelik öğrencilerinin genetik hastalık ve genetik danışmanlık bilgi durumları, STED. 2014; 23(2):50-58

11. Özkan S, Arslan FT. Hemşirelik ve ebelik öğrencilerinin genetik danışmanlık roller ile ilgili görüşleri. ACU Sağllk Bil Derg. 2019; 10(2): 22530.

12. Vural BK, Tomatır AG, Kurban NK, Taşpınar A. Nursing students' self-reported knowledge of genetics and genetic education, Public Health Genomics. 2009;12(4): 225-32.

13. Thompson HJ \& Brooks MV. Genetics and genomics in nursing: evaluating essentials implementation. Nurs Educ Today. 2011; 31(6):623-627.

14. Calzone KA, Cashion A, Feetham S et al. Nurses transforming health care using genetics and genomics. Nurs Outlook. 2010; 58(1): 26-35.

15. Underwood PC \& Read CY. Genetic association studies in nursing practice and scholarship. $J$ Nurs Scholarsh. 2008; 40(3):212-218.

16. Lea DH. Genetic and genomic healthcare: Ethical 1ssues of importance to nurses. The Online Journal of Issues in Nursing. 2008; 13(1):21-27.

17. Kirk M, Tonkin E, Skirton H. An iterative consensus-building approach to revising a genetics/genomics competency framework for nurse education in the UK. $J$ Adv Nurs. 2014;70(2):405-420.

18. Uluçay S, Çam FS. Genetik danışma nedir, nasıl verilir. Turkiye Klinikleri Tup Bilimleri Dergisi. 2016;1(1):51-55.

19. Calzone KA, Jenkins J, Culp S, Bonham VL, Badzek L. National nursing workforce survey of nursing attitudes, knowledge and practice in genomics. Per Med. 2013;10(7):18-24.

20. Godino L., Turchetti D., Skirton H. Knowledge of genetics and the role of thenurse in genetic health care: a survey of Italian nurses, $J$ Adv Nurs. 2013; 69(5): 1125-35. 